\title{
IFRS Adoption and Enforcement as Antecedents of Economic Growth
}

\author{
Syed Zaidi (Corresponding author) \\ Dept. of Accounting, California State University San Marcos \\ 333 S. Twin Oaks Valley Road, San Marcos CA 92096, United States
}

Tel: 1-760-750-4288Ｅ-mail: szaidi@csusm.edu

Esperanza Huerta

Accounting and Information Systems Department, The University of Texas at El Paso

500 West University Avenue, El Paso, TX 79968, United States

Tel: 1-915-747-7761_E-mail: ehuerta2@utep.edu

Accepted: April 01, 2014

DOI: 10.5296/ijafr.v4i1.5410 URL: http://dx.doi.org/10.5296/ ijafr.v4i1.5410

\begin{abstract}
This paper assesses the impact of IFRS adoption on the economic growth of adopting countries taking into consideration the level of enforcement of the adopting countries. We hypothesize that the adoption of IFRS increases the economic growth of the adopting countries. This effect is to be moderated by the level of enforcement. That is, we hypothesize a positive interaction between enforcement level and IFRS adoption on the economic growth rate of a country. Using several statistical procedures and models to estimate regression, we find partial support for our hypotheses.
\end{abstract}

Keywords: International Financial Reporting Standards (IFRS), Level of enforcement, Economic growth 


\section{Introduction}

International agencies such as the World Bank and the International Organization of Securities Commissions (IOSCO) promote the adoption of International Financial Reporting Standards (IFRS) to create a solid international financial infrastructure, which in turn should stimulate economic development of the adopting countries (Collins, 1989; Wyatt \& Yospe, 1993). The objective of this research is to assess the effect of IFRS adoption on the economic growth of adopting countries. However, adopting IFRS may not be enough to promote economic growth; enforcement mechanisms need to be in place to ensure IFRS compliance. Therefore, this research explores the joint effect of the level of enforcement and IFRS adoption on the economic growth of the adopting country.

The underlying benefit of IFRS adoption is to provide comparable and reliable financial statements to decision makers. In addition to the benefits for investors, IFRS adoption facilitates the development of world trade, which in turn promotes the economic growth of the adopting countries (Samuels \& Piper, 1985). International agencies stress the need of strong financial markets to foster economic development (Collins, 1989; Wyatt \& Yospe, 1993).

Since the beginning of the movement towards globalized accounting standards in the 1990s, research has attempted to gather empirical evidence on the impact of harmonized accounting standards on the economic growth of adopting countries. Studies conducted when the predecessors of the IFRS-the International Accounting Standards (IAS)-were in place, do not provide conclusive evidence. These early studies investigated the impact of IAS adoption on countries from a particular region (Africa (Larson, 1993) and Asia (Woolley, 1998)), or from a particular level of economic development (developing countries (Larson \& Kenny, 1995)). Some studies found that the adoption of IAS did not promote the economic growth (Larson \& Kenny 1995; Woolley, 1998), whereas one study found that IAS adaption promoted economic growth (Larson, 1993).

These early studies are important because they demonstrated the need to evaluate the impact of accounting standards on the economic growth of a country. However, much has changed since these studies were conducted. IAS have evolved into IFRS, the latter generally considered a more comprehensive set of standards. Also, IFRS have been adopted by developed countries. In the past, IAS adoption was common for developing countries, as developed countries already had their own set of standards in place. To expand our knowledge in this area, our study examines the impact of IFRS adoption on the economic growth of adopting countries including countries from different geographical areas as well as developing countries.

Our study also investigates the influence of a country's level of enforcement because mere adoption of IFRS is not enough to develop a solid financial infrastructure. As stressed by the World Bank (2004), the enforcement of the accounting and auditing standards is even more important than setting the standards; the lack of mechanisms to ensure compliance result in a weak financial reporting environment. 


\section{MInstitute Machin $_{\text {Int }}$}

International Journal of Accounting and Financial Reporting ISSN 2162-3082

Researchers have also proposed that the level of enforcement has an impact on the economic consequences resulting from IFRS adoption (Ashraf \& Ghani, 2005; Mir \& Rahaman, 2005; Ball, 2006; Daske, Hail, Leuz, \& Verdi, 2008; Armstrong, Barth, Jagolinzer, \& Riedl, 2008). However, the impact of enforcement when IFRS are adopted has not been empirically tested. To the best of our knowledge, no country level study investigating the impact of IFRS adoption on economic growth has been conducted since the development of IFRS in its current form.

The remainder of the paper is structured as follows. Section 2 provides the literature review and hypotheses development. Section 3 discusses the research method. Section 4 analyzes results. Section 5 provides discussion on findings. Section 6 discusses the limitations of the study and provides options for future research.

\section{Literature Review and Hypotheses Development}

IFRS are part of the accounting infrastructure that helps countries to promote their economic growth (Larson \& Kenny, 1996). Researchers suggest that IFRS adoption improves the transparency and disclosure of financial statements (Leuz \& Verrechia, 2000; Ball, 2006; Lambert, Leuz, \& Verrechia, 2007; Barth, Landsman, \& Lang, 2008). Improved transparency and disclosure should reduce uncertainty, agency cost, information asymmetry, cost of capital, and estimation risk, while enhancing credibility, comparability, accuracy, information quality, accounting quality, corporate governance, market liquidity, and capital market efficiency (Leuz \& Verrecchia, 2000; Jermakowicz, 2004; Ball, 2006; Jermakowicz \& Gornik-Tomaszewski, 2006; Lambert et al., 2007; Armstrong et al., 2008; Barth et al., 2008).

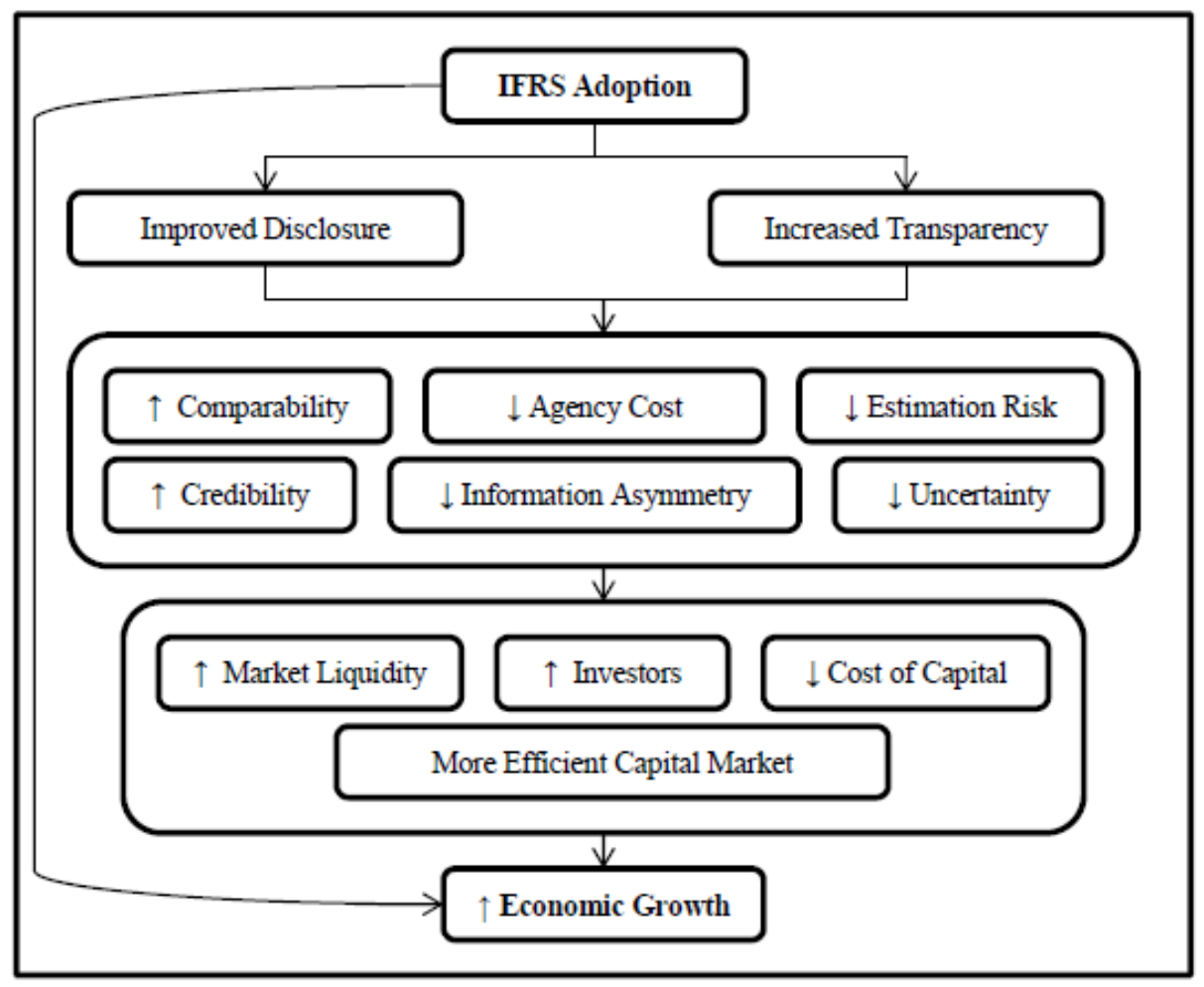

Figure 1. Impact of IFRS Adoption. 


\section{Mll Macrothink}

International Journal of Accounting and Financial Reporting

ISSN 2162-3082

2014, Vol. 4, No. 1

The impact of accounting standards on financial markets is supported by bonding theory, which suggests that improved disclosure and better accounting standards signal investors of an increase in quality of the financial statements (Coffee, 2002). Better financial statements increase transparency which, in turn, attracts more investors and promotes efficient capital markets (Leuz \& Verrecchia, 2000; Drabek \& Payne, 2002; Lang, Lins, \& Miller, 2003; Jermakowicz, 2004; Ball, 2006; Jermakowicz \& Gornik-Tomaszewski, 2006; Lambert et al., 2007; Barth et al., 2008). Lee (1987) suggests that efficient capital markets promote economic development. Therefore, the adoption of IFRS should have a positive impact on the economic growth of adopting countries. Figure 1 illustrates the impact of IFRS adoption on the efficiency of capital markets, which in turn impact the economic growth of adopting countries.

The impact of IFRS adoption on a country's economic growth has been a constant topic of debate among researchers, accounting professionals, and regulatory authorities. However, limited empirical research has been conducted to support these arguments. Although several studies investigate the impact of IFRS adoption at the firm level, we identified three studies testing the economic consequences of IFRS adoption on adopting countries. These studies were conducted when IAS were in place.

Larson (1993) conducted a cross-sectional study including data from 35 African countries to determine whether the economic growth of countries that adopted or adapted IAS differed from those of non-adoptee countries. The author found that countries that adapted IAS to meet local environmental factors experience larger economic growth than countries that either adopted IAS wholesale or did not adopt IAS at all.

Similar to Larson's (1993) research, Woolley (1998) conducted a study to examine the differences in economic growth rates between IAS adoptee and non-adoptee countries in Asia (Cited in Zeghal \& Mhedhbi, 2006). The author found no significant differences in the economic growth rates of IAS adoptee and non-adoptee countries.

Larson and Kenny (1995) conducted a study including 27 developing countries that have equity markets to determine the effects of IAS adoption on equity market development and economic growth. They found a small negative relationship between IAS adoption and economic growth rates in the developing countries studied.

In summary, these studies report conflicting findings. In terms of the impact of IAS adoption on the economic growth, one study reported a positive impact (Larson, 1993), another reported a small negative impact (Larson \& Kenny, 1995), and the other study reported no impact (Woolley, 1998).

In addition, much has changed since these early studies. In 1995, the International Accounting Standard Committee (IASC, now Board IASB) entered into an agreement with IOSCO to produce a core set of standards (Gornik-Tomaszweski \& McCarthy, 2003). In 2000, IOSCO endorsed the standards developed by IASC (Gornik-Tomaszweski \& McCarthy, 2003; Kwok \& Sharp, 2005; Radebaugh, Gray, \& Black, 2006).

The adoption of IFRS has become widespread since the establishment of the IASB in 2001 as 


\section{MInstitute Macrothink $_{\text {Int }}$}

International Journal of Accounting and Financial Reporting

ISSN 2162-3082

2014, Vol. 4, No. 1

the successor of IASC. IFRS include a framework for the preparation and presentation of financial statements; this framework was lacking in IAS. This framework states basic principles and grounds of IFRS. IFRS are more comprehensive than their predecessors (IAS) and are considered an improved set of standards (Hicks, 2010; Deloitte, 2010). Conflicting results on the economic growth of adopting countries might be explained by the limited impact of IAS on the quality of the financial statements reported.

Although there are a few studies investigating the impact of IFRS adoption at the country level, several studies have been conducted at the firm level. These studies have tested the effect of IFRS adoption on market liquidity, stock price, bid-ask spread, and accounting quality among others. These factors impact the efficiency of capital markets, which then influence the economic growth of a country (see Figure 1).

For example, higher stock market liquidity, lower bid-ask spread, lower cost of equity capital and higher accounting quality are desired attributes of an efficient market (Leuz \& Verrecchia, 2000; Jermakowicz, 2004; Ball, 2006; Jermakowicz \& Gornik-Tomaszewski, 2006; Lambert et al., 2007; Armstrong et al., 2008; Barth et al., 2008). Gassen and Sellhorn (2006) found that the German firms that adopt IFRS experience a decline in the bid-ask spread. Similarly, Daske et al. (2007) also found that "serious" adopters experience an increase in the market liquidity and a decrease in the bid-ask spread and the cost of capital. In another study, Daske et al. (2008) found a significant increase in the stock market liquidity and a decrease in the cost of capital for the mandatory adopters.

Given the expected impact of IFRS on the economic growth of a country through the efficiency of its capital market, we propose the following hypothesis:

H1: There is a positive relationship between IFRS adoption and the economic growth rate of a country.

Larson and Kenny (1995) suggest that mere adoption of IFRS does not lead to greater equity market development and economic growth. Enforcement plays an important role in this regard. Enforcement is the act of enforcing rules and laws; it is the imposition of compliance or adherence to the designated guidelines. From the perspective of IFRS adoption, enforcement implies that the financial statements that companies report adhere to the regulations established in the IFRS. Enforcement plays a crucial role in the implementation of standards. If a country adopts IFRS but does not enforce them, the reliability of the financial statements reported can be doubtful. When enforcement mechanisms are active, the financial statements reported adhere to IFRS, and the overall accounting quality improves.

The IASB and other international organizations promote IFRS adoption but they cannot enforce their use (Ball, 2006). Only local authorities, such as financial market regulators, have the power to enforce the use of the IFRS (Soderstrom \& Sun, 2007). The International Organization of Securities Commissions (IOSCO), which not only develops but also promotes securities regulation standards, advises member countries to adopt IFRS; however, it also lacks the authority to enforce them (Ball, 2006).

The local political and economic circumstances of a country have a significant impact on its financial 


\section{Mll Macrothink}

International Journal of Accounting and Financial Reporting

ISSN 2162-3082

2014, Vol. 4, No. 1

reporting practices (Ball, 2006). For instance, Pakistan adopted IAS in 1985; however, IAS adoption did not improve the quality of financial reporting because enforcement mechanisms were not in place (Ashraf \& Ghani, 2005). Enforcement mechanisms related to financial reporting include auditing and disciplinary procedures for non-compliance (Mir \& Rahaman, 2005). Only countries with strict enforcement mechanisms can experience capital market benefits (Daske et al., 2008).

Ashraf and Ghani (2005), Mir and Rahaman (2005), Ball (2006), Daske et al. (2008), and Armstrong et al. (2008) suggest that the level of enforcement of adopting countries has a significant impact on the economic consequences of IFRS adoption. However, this relationship has not been empirically tested. Based on their argument, the level of enforcement can leverage the gains derived from IFRS adoption. Countries should gain more benefits when they adopt IFRS and have a high level of enforcement. The combined impact of IFRS adoption and enforcement level suggests the moderating effect of enforcement level on IFRS adoption. Therefore, we test the level of enforcement as a variable moderating the relationship between IFRS adoption and economic growth rate.

H2: The level of enforcement moderates the impact of IFRS adoption on the economic growth rate of a country.

\section{Research Method}

We use archival data for this study. The sample includes countries that have adopted and have not adopted IFRS. Non-adopting countries are matched to adopting countries based on the average of five years pre-adoption GDP growth rate. This matched-pair strategy is similar to the matching strategy used by Zeghal and Mhedhbi (2006). Ordinary least square (OLS) and two-stage least square (2SLS) regression analyses are performed to test the influence of IFRS adoption and level of enforcement on the three year economic growth rate post-adoption of a country. The following section provides a description of the variables of the study.

\subsection{Variables}

The dependent variable is the average growth rate of GDP per capita for 3 years after IFRS adoption $(A G D P 3 Y)$. The GDP Data are collected from the World Development Indicators (World Bank Website) current on September 24, 2010. Average growth rate of GDP is considered an adequate proxy for economic growth. Larson and Kenny (1995) also use GDP per capita to investigate the impact of IFRS adoption on the economic growth of adopting countries. GDP growth rate is the change in GDP from one period to another and is an indicator economic wealth. It is unlikely that IFRS adoption would have an immediate effect on the economic growth of a country; most likely the effect will lag several years. Prior research has considered data for more than one year post-adoption (Larson, 1993; Larson \& Kenny, 1995). Although it is not clear the number of years after adoption in which the effects of IFRS will take place, previous research has used total percentage change in GDP and GDP per capita from 1983 to 1988 (Larson, 1993) and from 1985 to 1989 (Larson \& Kenny, 1995). However, due to lack of GDP data availability, we use the average of three years GDP per capita after IFRS adoption.

Adoption refers to the country-level adoption of IFRS as issued by the IASB. This information is drawn from Deloitte's website (www.iasplus.com). Deloitte's website does not 
differentiate among adoption, adaption, and convergence and provides the information regarding the direct use of IFRS in countries or regions. Deloitte's website indicates that "direct use means that the basis of preparation note and the auditor's report will refer to conformity with IFRS" (www.iasplus.com; September 29, 2009). Hope et al.'s (2006) use the direct use of IFRS as indicated in the Deloitte's data for classifying a country as an IFRS adopter or not. Following Hope et al., (2006), we also classify a country as IFRS adopter based on Deloitte's data of direct use of IFRS. Adoption of IFRS (ADOPT) is an independent variable with a value of zero if a country has not adopted IFRS and one otherwise.

Level of enforcement ( $L E N F)$ measures the "perceptions of the extent to which agents have confidence in and abide by the rules of society, and in particular the quality of contract enforcement, property rights, the police, and the courts, as well as the likelihood of crime and violence" (Kaufmann et al., 2008, p.7). LENF is included also as a moderator variable to test whether an interaction exists between level of enforcement and IFRS adoption. We use Kaufmann et al. (2009) rule of law index to measure the level of enforcement in a particular country. We use Kaufmann et al. (2009) indices for two reasons. First, their indices range from 1996 to 2008, which covers the period of our study. Second, they measured indices for 212 countries, including the countries investigated in this study ${ }^{1}$.

This study focuses on the impact of IFRS adoption and level of enforcement on the economic growth of adopting countries. However, other factors can also play a role in the economic growth of a country. In the presence of these factors, the expected influence of IFRS would be marginal. Therefore, considering the importance of these factors, we include five factors in the model. These factors are: (1) corruption, (2) level of education, (3) foreign direct investment, (4) level of development, and (5) political stability. These variables have been selected for various reasons. Some have been selected because they were included in past research due to their importance; such as level of education (Larson, 1993; Larson \& Kenny, 1995), level of development (Larson, 1993), and political stability (Larson \& Kenny, 1995). Corruption is selected because it can impede the economic growth of a country (Bardhan, 1997). Foreign direct investment is included because it can influence the economic growth (De Mello, 1999). In addition, we include European Union as the sixth control variable since most IFRS adoptee countries included in our model belong to the European Union.

\section{Table 1. Description of Variables}

\begin{tabular}{|l|l|l|l|}
\hline \multicolumn{1}{|c|}{ Variables } & \multicolumn{1}{c|}{ Type } & \multicolumn{1}{c|}{ Definition } & \multicolumn{1}{c|}{ Operationalization } \\
\hline $\begin{array}{l}\text { Average growth } \\
\text { rate of GDP per } \\
\text { capita post 3 years } \\
\text { of IFRS adoption } \\
\text { (AGDP3Y) }\end{array}$ & $\begin{array}{l}\text { Dependent } \\
\text { (continuous) }\end{array}$ & $\begin{array}{l}\text { It is an indicator of } \\
\text { economic health which } \\
\text { measures the change in } \\
\text { GDP from one period to } \\
\text { another. }\end{array}$ & $\begin{array}{l}\text { Average of the annual growth } \\
\text { rate of GDP per capita of a } \\
\text { country during the three } \\
\text { years post IFRS adoption. }\end{array}$ \\
\hline $\begin{array}{l}\text { Adoption of IFRS } \\
\text { (ADOPT) }\end{array}$ & $\begin{array}{l}\text { Independent } \\
\text { (dummy) }\end{array}$ & $\begin{array}{l}\text { It refers to the direct use } \\
\text { of IFRS as issued by the }\end{array}$ & $\begin{array}{l}\text { Not adopted =0 } \\
\text { Adopted =1 }\end{array}$ \\
\hline
\end{tabular}

\footnotetext{
${ }^{1}$ La Porta et al. (1998) reported indices for only 49 countries. Unlike Kaufmann et al. (2009), La Porta et al. (1998) indices are not available for multiple years.
} 


\begin{tabular}{|c|c|c|c|}
\hline Variables & Type & Definition & Operationalization \\
\hline & & IASB by a country. & \\
\hline $\begin{array}{l}\text { Enforcement } \\
\text { (LENF) }\end{array}$ & $\begin{array}{l}\text { Independent } \\
\text { (continuous) }\end{array}$ & $\begin{array}{l}\text { It measures the degree } \\
\text { "to which agents have } \\
\text { confidence in and abide } \\
\text { by the rules of society" } \\
\text { (Kaufmann et al., 2008; } \\
\text { p.7). }\end{array}$ & $\begin{array}{l}\text { Rule of law index from } \\
\text { Kaufmann et al. (2009). This } \\
\text { index ranges from }-2.5 \text { to } 2.5 \text {. } \\
\text { Higher values indicate higher } \\
\text { levels of enforcement. }\end{array}$ \\
\hline $\begin{array}{l}\text { Corruption } \\
\text { (CORRUP) }\end{array}$ & $\begin{array}{l}\text { Control } \\
\text { (continuous) }\end{array}$ & $\begin{array}{l}\text { It is the level of } \\
\text { exploitation of power } \\
\text { for personal gains. }\end{array}$ & $\begin{array}{l}\text { Corruption index is taken } \\
\text { from Kauffman et al. (2009) } \\
\text { and ranges from }-2.5 \text { to } 2.5 \text {, } \\
\text { where higher values indicate } \\
\text { lower levels of corruption. }\end{array}$ \\
\hline $\begin{array}{l}\text { Level of education } \\
\text { (LOE) }\end{array}$ & $\begin{array}{l}\text { Control } \\
\text { (continuous) }\end{array}$ & $\begin{array}{l}\text { It is the literacy rate in a } \\
\text { given country. }\end{array}$ & $\begin{array}{l}\text { LOE is the percentage of } \\
\text { primary school enrollment. } \\
\text { Data are taken from the WDI } \\
\text { and ranges from } 0 \text { to } 100 \\
\text { where higher values indicate } \\
\text { higher levels of education. }\end{array}$ \\
\hline $\begin{array}{l}\text { Foreign direct } \\
\text { investment (FDI) }\end{array}$ & $\begin{array}{l}\text { Control } \\
\text { (continuous) }\end{array}$ & $\begin{array}{l}\text { It is the investment } \\
\text { received within a } \\
\text { country from foreign } \\
\text { countries. }\end{array}$ & $\begin{array}{l}\text { FDI is the net inflows of FDI } \\
\text { as a percentage of GDP. FDI } \\
\text { data are taken from the WDI. } \\
\text { Higher values indicate higher } \\
\text { levels of FDI. }\end{array}$ \\
\hline $\begin{array}{l}\text { Level } \\
\text { development } \\
\text { (LOD) }\end{array}$ & $\begin{array}{l}\text { Control } \\
\text { (dummy) }\end{array}$ & $\begin{array}{l}\text { It is the economic } \\
\text { development status of a } \\
\text { country, such as } \\
\text { developed, emerging, } \\
\text { developing, or under } \\
\text { developed countries. }\end{array}$ & $\begin{array}{l}\text { Level of development of } \\
\text { countries is based on GNI per } \\
\text { capita. Higher values indicate } \\
\text { higher levels of development. }\end{array}$ \\
\hline $\begin{array}{l}\text { Political stability } \\
\text { (PS) }\end{array}$ & $\begin{array}{l}\text { Control } \\
\text { (continuous) }\end{array}$ & $\begin{array}{l}\text { It is the perception that } \\
\text { the government will not } \\
\text { be overthrown or } \\
\text { destabilized by } \\
\text { unconstitutional means. }\end{array}$ & $\begin{array}{l}\text { Political stability index is } \\
\text { taken from Kauffman et al. } \\
\text { (2009) and ranges from }-2.5 \\
\text { to } 2.5 \text {, where the higher } \\
\text { values indicate higher levels } \\
\text { of political stability. }\end{array}$ \\
\hline $\begin{array}{l}\text { European Union } \\
(\mathrm{EU})\end{array}$ & $\begin{array}{l}\text { Control } \\
\text { (dummy) }\end{array}$ & $\begin{array}{l}\text { It indicates whether a } \\
\text { country belongs to the } \\
\text { European Union or not. }\end{array}$ & $\begin{array}{l}\text { Not a European Union } \\
\text { country }=0 \\
\text { European Union Country }=1\end{array}$ \\
\hline
\end{tabular}

Indices for corruption and political stability are taken from Kaufmann et al. (2009). Data regarding level of education, foreign domestic investment, and level of development are taken from the World Development Indicators (World Bank Website). European Union is a dummy variable that identifies membership to the European Union. Table 1 provides the 
description of variables.

\subsection{Model}

Ordinary least square and two-stage least square regression analyses are performed to test the hypotheses using the following regression model.

AGDP3Y $_{i}=\beta_{0}+\beta_{1}$ ADOPT $_{\mathrm{i}}+\beta_{2} \mathrm{LENF}_{\mathrm{i}}+\beta_{3}\left(\mathrm{ADOPT}_{\mathrm{i}}\right)\left(\mathrm{LENF}_{\mathrm{i}}\right)+\beta_{4} \mathrm{CORRUP}_{\mathrm{i}}+\beta_{5} \mathrm{LOE}_{\mathrm{i}}+$ $\beta_{6} \mathrm{FDI}_{\mathrm{i}}+\beta_{7} \mathrm{LOD}_{\mathrm{i}}+\beta_{8} \mathrm{PS}_{\mathrm{i}}+\beta_{9} \mathrm{EU}_{\mathrm{i}}+\varepsilon_{\mathrm{i}}$

$\beta_{1}$ and $\beta_{2}$ are the main effects of IFRS adoption and level of enforcement, $\beta_{3}$ is the interaction term between IFRS adoption and level of enforcement, and $\beta_{4}$ through $\beta_{9}$ are control variables.

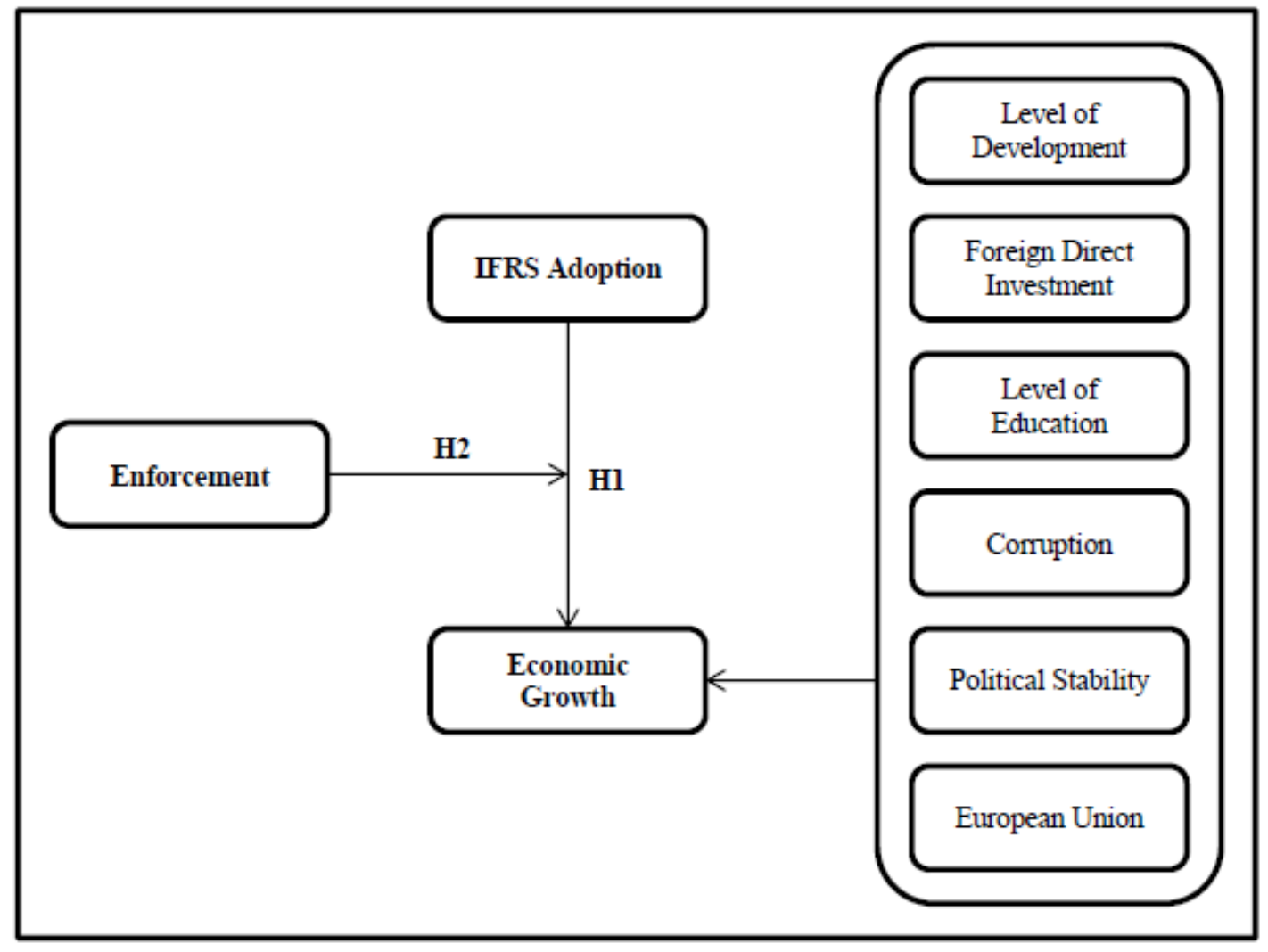

Figure 2: Research Model of the Impact of IFRS Adoption on Economic Growth.

Figure 2 presents the research model. It shows that the impact of IFRS adoption on the economic growth of the adoptee country is moderated by the country's level of enforcement. The figure shows other factors (control variables) that can also affect the economic growth of the adoptee countries.

\subsection{Sample}

The initial sample for this study includes countries listed in iasplus.com totaling 172 countries. The final sample includes 51 countries that have adopted IFRS by 2007 and 51 countries that had not adopted by the same date. The final number of countries in the sample was the result of the availability of the data. Following is a description of the process 
followed to compose the sample.

In the first step, we identify countries that have a stock exchange and have adopted IFRS. Iasplus.com lists 173 jurisdictions (172 countries) indicating the standards followed by domestic listed and unlisted companies and if a domestic stock exchange exists. When the country has a stock exchange, the list indicates whether the use of IFRS to prepare financial statements is permitted, not permitted, required for all (public and private), or required for some companies.

We exclude from the sample jurisdictions where no stock exchange exists (19 jurisdictions). One of the objectives of IFRS adoption is to assist foreign investors in evaluating investment decisions in a particular country. When no stock exchange exists within a country, investments are not public but private reducing the potential impact of IFRS adoption. We also exclude countries with stock exchanges where IFRS are permitted (26 jurisdictions), not permitted (31 jurisdictions), and required for some (6 jurisdictions). When a country permits but does not require IFRS for financial statement reporting, companies may opt for not reporting using IFRS. That is, when companies have the option of using IFRS, the portion of companies reporting using IFRS is not directly known and the potential impact of IFRS adoption may be diluted. Only when a country requires IFRS for listed companies, can it be certain that companies are using IFRS to report their financial information. Therefore, countries that permit but do not require IFRS have also been excluded from the sample. Considering these requirements, the resulting sample includes 81 jurisdictions with stock exchanges where IFRS is required for all listed companies by 2007.

Countries that adopted IFRS after 2007 are not included in the sample for design purposes. This study analyzes the average growth rate of the GDP per capita for three years after a country adopts IFRS. Given that several years of data after IFRS adoption are required, we limit the year of IFRS adoption to 2007, so the post-adoption data can include 3 years of GDP growth rate. Year of IFRS adoption is obtained mainly from www.iasplus.com and www.ifac.org. When the information about the year of adoption is not available on Deloitte, IFAC, or any other websites, those countries are also dropped from the sample. The final sample consists of 51 IFRS adoptee countries and 51 matched sample for a total sample size of 102 countries.

\subsection{Matched Pair Strategy}

The final sample consists of 51 IFRS countries that have adopted IFRS between 1997 and 2007. Following Zeghal and Mhedhbi (2006), we include a matched sample of non-adoptees. First, we rank the group of adoptee and the group of non-adoptee countries based on their average GDP growth rate of five years pre-adoption. Then we match the countries in the two groups on the basis of their respective ranks ${ }^{2}$. The matched sample is created based on the closest average annual growth rate of GDP per capita during the last five years before IFRS adoption. The matched pair strategy is similar to the strategy used by Zeghal and Mhedhbi (2006).

\footnotetext{
2 The resulting matched sample is provided in Appendix A.
} 


\section{Macrothink \\ International Journal of Accounting and Financial Reporting \\ ISSN 2162-3082 2014, Vol. 4, No. 1}

\section{Analysis and Results}

We begin our analysis by examining if the variables comply with the assumptions of regression. First, we test for normality and find that the assumption for normality is violated. To fix this problem, we transform the data by calculating the natural log of the dependent variable (LN_AGDP3Y). We retest the assumption of normality for LN_AGDP3Y and find that assumption of normality is still violated. A box plot reveals the presence of an influential observation (Italy). We, then, use several statistical measures, such as residuals, leverage, Cook's D, DFBETA, and scatter plots, to examine outliers. We find Italy as the influential observation in all analyses. Therefore, we exclude Italy and its matched country Benin from further analyses. Next, we examine if the variables comply with the remaining assumptions of regression. We test for linearity, homoscedasticity, and independence. We do not find any major violation of any assumption. We also test for multicolliearity and found that corruption and level of enforcement are highly correlated. 


\section{Macrothink}

Table 2: Means, Standard Deviations, and Pearson Bivariate Correlations

\begin{tabular}{|c|c|c|c|c|c|c|c|c|c|c|c|c|}
\hline Variable & Mean & SD & 1 & 2 & 3 & 4 & 5 & 6 & 7 & 8 & 9 & 10 \\
\hline 1. AGDP3Y & 3.463 & 3.325 & - & & & & & & & & & \\
\hline 2. ADOPT & 0.490 & 0.503 & -.147 & - & & & & & & & & \\
\hline 3. LENF & 2.722 & 0.983 & $-.246^{* *}$ & $.429^{* * *}$ & - & & & & & & & \\
\hline 4. ADOPT_LENF & 1.541 & 1.707 & $-.192^{*}$ & $.928^{* * *}$ & $.639^{* * *}$ & - & & & & & & \\
\hline 5. PS & 2.602 & 0.895 & $-.180^{*}$ & $.440^{* * *}$ & $.824^{* * *}$ & $.571^{* * *}$ & - & & & & & \\
\hline 6. LOD & 10407.930 & 14562.048 & $-.306^{* * *}$ & $.342^{* * *}$ & $.829^{* * *}$ & $.561^{* * *}$ & $.609^{* * *}$ & - & & & & \\
\hline 7. CORRUP & 2.706 & 1.045 & $-.320 * * *$ & $.422^{* * *}$ & $.958^{* * *}$ & $.626^{* * *}$ & $.784^{* * *}$ & $.860 * * *$ & - & & & \\
\hline 8. LOE & 89.125 & 12.544 & -.043 & $.369^{* * *}$ & $.480^{* * *}$ & $.404^{* * *}$ & $.351^{* * *}$ & $.404 * * *$ & $.427 * * *$ & - & & \\
\hline 9. FDI & 6.853 & 24.660 & .078 & .098 & .135 & .144 & .114 & $.299 * * *$ & .113 & .067 & _ & \\
\hline 8. EU & 0.270 & 0.447 & -.037 & $.624^{* * *}$ & $.599^{* * *}$ & $.770^{* * *}$ & $.489^{* * *}$ & $.496 * * *$ & $.585 * * *$ & $.354 * * *$ & .146 & - \\
\hline
\end{tabular}

AGDP3Y =Average Growth Rate of GDP per Capita Post Three Years of IFRS Adoption; ADOPT = IFRS Adoption; LENF = Level of Enforcement; ADOPT_LENF = Interaction between ADOPT and LENF; PS = Political Stability; LOD = Level of Development; CORRUP = Corruption; $\mathrm{LOE}=$ Level of Education; FDI $=$ Foreign Direct Investment; EU = European Union; $\mathrm{p}<0.10=* ; \mathrm{p}<0.05=* * ; \mathrm{p}<0.01=* * *$ 
Table 2 reports means, standard deviations, and Pearson bivariate correlations among dependent and independent variables. Pearson bivariate correlations show high correlation among corruption, political stability, level of development, and level of enforcement suggesting the possible presence of multicollinearity.

Multicollinearity is confirmed by variance inflation factor (VIF) values above 10 (Marquardt, 1970; Cohen et al., 2003) for level of enforcement, corruption, and interaction between IFRS adoption and level of enforcement. In order to reduce VIF, we center all independent variables except dummy variables. The analysis with the centered variables still indicates high VIF for level of enforcement and corruption. Cohen et al., (2003) recommend using model respecification approach to solve multicollinearity problem. The authors suggest two techniques of model respecification: (1) dropping one (or more) independent variables from the regression equation and (2) revising regression model by combining the correlated variables into a single index. We use both techniques to resolve multicollinearity problem.

We use different methods to enter the variables into the regression model to test our hypotheses. These methods include enter, stepwise (results not reported), block (results not reported), and two-stage least square regression. Enter is the most widely used method in this kind of research; therefore, we report results using the enter method. In most of these analyses, ADOPT and the interaction between ADOPT and LENF are not found to be significant.

We use different variations of the dependent variable to test the impact of IFRS adoption on the economic growth rate of adopting countries since it is not known how long it takes for the adoption of IFRS to make an impact on the economic growth rate of adoptee countries. Therefore, we modify the original model including all independent variables but different dependent variables as mentioned below. These variations of the dependent variable include, in addition to the original average growth rate of GDP per capita post 3 years of IFRS adoption (results are reported in Section 4.1), average growth rate of GDP per capita post 5 years of IFRS adoption (results not reported), and change in the average growth rate of GDP per capita between pre 5 years and post 3 years of IFRS adoption (results not reported), and growth rate of GDP per capita post 1 year (results not reported), post 2 years (results not reported), and post 3 years (results not reported) of IFRS adoption. In addition, we also estimate the model using two-stage least square (2SLS) regression method (discussion is provided in Section 4.2). Finally, we estimate the model using growth rate of GDP per capita in 2010 (discussion is provided in Section 4.3). The 2SLS analysis supports Hypothesis 1 and the model with GDP2010 as a dependent variable supports Hypothesis 2.

In addition, each model is estimated using different methods to treat missing values including listwise, pairwise (results not reported), and meansubstitution (results not reported). We use several variations as robustness checks to determine whether the methods for treating missing variables influence the results. However, we rely on the most commonly used method, listwise deletion, for reporting purposes. Overall, the results are found to be consistent; however, the level of significance changed from listwise to pairwise to meansubstitution.

We also test all models using two different variations of the sample: (1) adoptee and non-adoptee sample and (2) adoptee only sample (results not reported). These variations are used as robustness check to determine whether the use of different samples to test the impact of IFRS adoption on the economic growth of a country influences the results. We find that, exclusion of non-adoptee countries from the sample does affect the results. The results obtained from using adoptee only sample do not support any hypotheses. 


\subsection{Original Model}

The results of the ordinary least square regression for four different models are displayed in Table 3. We use several variations of the sample to estimate these models. These variations include: sample excluding countries with a negative growth rate with the dependent variable AGDP3Y (Table 3), original sample including countries with a negative growth rate with the dependent variable AGDP3Y (results not reported), more conservative sample excluding countries with a negative growth rate and their matched sample with the dependent variable AGDP3Y (results not reported), and original sample with a log of the dependent variable (LN_AGDP3Y) (results not reported). These variations are used as robustness tests to determine whether changing the sample size or transforming the dependent variable influence the results. Mostly, these variations provide consistent results with slightly different explanatory powers.

The estimated regression model including all independent variables, as proposed in Section 3.2 (Model 4 in Table 3), indicate multicollinearity problems. The Variance Inflation Factor (VIF) for C_LENF and C_CORRUP are above the recommended limit of 10 (Marquardt, 1970; Cohen, Cohen, West, \& Aiken 2003) (C_LENF = 18.403, C_CORRUP = 16.001). As stated earlier, Cohen et al., (2003) recommend using model respecification approach to solve multicollinearity problems. We use two techniques of model respecification: (1) dropping one (or more) independent variables from the regression equation and (2) revising the regression model by combining the correlated variables into a single index.

Table 3: Ordinary Least Square Regression Analysis for Predictors of AGDP3Y

\begin{tabular}{|c|c|c|c|c|}
\hline Variable & Model 1 & Model 2 & Model 3 & Model 4 \\
\hline \multicolumn{5}{|l|}{ Main Effects } \\
\hline ADOPT & $-0.236^{*}$ & $-0.253^{*}$ & -0.228 & $-0.222 *$ \\
\hline C_LENF & $-0.428^{* *}$ & $-0.559 * *$ & -0.321 & 0.200 \\
\hline \multicolumn{5}{|l|}{ Interaction } \\
\hline ADOPT x C_LENF & -0.120 & -0.096 & -0.009 & -0.067 \\
\hline \multicolumn{5}{|l|}{ Control Variables } \\
\hline C_PS & & 0.138 & 0.084 & 0.103 \\
\hline C_LOD & & & -0.308 & -0.128 \\
\hline C_CORRUP & & & & $-0.669 *$ \\
\hline C_LOE & 0.118 & 0.136 & 0.145 & 0.111 \\
\hline C_FDI & 0.128 & 0.127 & $0.185^{*}$ & 0.140 \\
\hline $\bar{E} \bar{U}$ & $0.321^{*}$ & $0.321^{*}$ & 0.272 & $0.305^{*}$ \\
\hline F-value & $3.235 * * *$ & $2.841 * *$ & $2.796 * * *$ & $2.861 * * *$ \\
\hline $\mathrm{N}$ & 86 & 86 & 86 & 86 \\
\hline $\mathrm{R}^{2}$ & 0.197 & 0.203 & 0.225 & 0.253 \\
\hline Adjusted $\mathrm{R}^{2}$ & 0.136 & 0.132 & 0.145 & 0.165 \\
\hline \multicolumn{5}{|c|}{$\begin{array}{l}\text { AGDP3Y = Average Growth Rate of GDP per Capita Post Three Years of IFRS Adoption; } \\
\text { ADOPT = IFRS Adoption; C_LENF = Level of Enforcement }(\text { Centered); ADOPT x C_LENF } \\
=\text { Interaction between Adoption and the Level of Enforcement; C_PS = Political Stability } \\
\text { (Centered); C_LOD = Level of Development (Centered); C_CORRUP = Corruption } \\
\text { (Centered); C_LOE = Level of Education (Centered); C_FDI = Foreign Direct Investment } \\
\text { (Centered); EU = European Union; }<<0.10=* ; \mathrm{p}<0.05=* * ; \mathrm{p}<0.01=* * *\end{array}$} \\
\hline
\end{tabular}

Following model respecification technique 1, several variations of the original proposed 
model are tested. The original model is identified in Table 3 as Model 4. The variations of the model are as follows. Model 1 excludes political stability, level of development, and corruption. Model 2 excludes level of development and corruption. Model 3 excludes corruption. The results show the following effects on the dependent variable (average growth rate of GDP per capita post 3 years of IFRS adoption). IFRS adoption has a significant and negative impact in model 1 , model 2 , and model 4 . Level of enforcement has a significant and negative impact in model 1 and model 2. Corruption has a significant and negative impact in model 4. Foreign Direct Investment has a significant and positive impact in model 3. European Union has a significant and positive impact in model 1, model 2, and model 4. The interaction shows a negative relationship with the dependent variable in all models; however, the results are not statistically significant at $10 \%$ level. The $\mathrm{R}^{2}$ values for model 1 , model 2, model 3, and model 4 are 19.7\%, 20.3\%, 22.5\%, and 25.3\%. Results from the original model proposed in Section 3.2 (Model 4 in Table 3) find no support for the hypotheses.

Following model respecification technique 2, we aggregate the variables that showed multicollinearity with Principal Component Analysis (Varimax Rotation). We create a composite variable and replace the highly correlated variables with the composite variable in the regression. Combining highly correlated variables into a single measure can help solving multicollinearity problem (O'Brien, 2007). We estimate seven different variations of models (results not reported). These models test different combinations of composite variables as explained below. We use several variations as robustness checks to determine whether the number of variables used to create the composite variable influenced the results. Each model is estimated twice, once with the log (LN_AGDP3Y) and once without the log (AGDP3Y) of a dependent variable.

Correlations results show high correlation between LENF and CORRUP, PS, and LOD. Therefore, we create several composite variables combining different independent variables through factor analysis. In model 1, the composite variable includes CORRUP, PS, and LOD. We replace the variables CORRUP, PS, and LOD with the composite variable; however, we do not find support for any hypotheses (results not reported). In model 2, the composite variable includes LENF, CORRUP, PS, and LOD (results not reported. In model 3, the composite variable includes LENF, CORRUP and PS (results not reported). We exclude LOD from this analysis. Model 4 uses the composite variable created for model 3 and includes LOD as a control variable (results not reported). In model 5 , the composite variable includes LENF and CORRUP. We exclude the other two correlated variables (PS and LOD) from this model (results not reported). Model 6 and model 7 are similar to model 5 but model 6 includes PS as a control variable and model 7 includes both PS and LOD as control variables (results not reported). Overall, we do not find support for our hypotheses.

\subsection{Model Endogeneity}

Extent literature suggests that a reciprocal relationship may exist between a country's accounting standards and economic growth (Larson, 1993; Zeghal \& Mhedhbi, 2006). The high economic growth of a country may lead to the development of accounting standards. This suggests that if countries experience high economic growth, they can choose to adapt or adopt the standards that fits them the best. This means adoption of IFRS does not lead to higher economic growth rather the higher economic growth leads to the adaption or adoption of IFRS. Due to the reciprocal relationship between the dependent variable, average growth rate of GDP per capita, and the independent variable, IFRS adoption, it is not clear whether IFRS adoption leads to the higher economic growth or the higher economic growth leads to 
IFRS adoption. Therefore, the independent variable, adoption, is an endogenous to the dependent variable, average growth rate of GDP per capita post 3 years of IFRS adoption ${ }^{3}$. Endogeneity causes regression coefficients to be biased. Following Chenhall and Moers (2007), we estimate two-stage least square (2SLS) regression to control for endogeneity ${ }^{4}$.

Table 4 shows the results obtained from the 2SLS regression. We test several variations of the original proposed model. The original model is identified in Table 4 as Model 4. The variations of the model are as follows. Model 1 excludes political stability, level of development, and corruption. Model 2 excludes level of development and corruption. Model 3 excludes corruption. The results show the following effects on the dependent variable (average growth rate of GDP per capita post 3 years of IFRS adoption). IFRS adoption has a significant and positive impact in model 2 , model 3 , and model 4 . The interaction shows a negative relationship with the dependent variable in all models; however, the results are not statistically significant. The $\mathrm{R}^{2}$ values for model 1 , model 2 , model 3 , and model 4 are $20.5 \%$, $27.0 \%, 28.2 \%$, and $35.7 \%$. Results from model 2, model 3, and model 4 support hypothesis 1.

Table 4: Two-Stage Least Square Regression Analysis for Predictors of AGDP3Y

\begin{tabular}{|c|c|c|c|c|}
\hline Variable & Model 1 & Model 2 & Model 3 & Model 4 \\
\hline \multicolumn{5}{|l|}{ Main Effects } \\
\hline E_ADOPT & 1.336 & $15.171 * * *$ & $15.816^{* * *}$ & $22.171 * * *$ \\
\hline C_LENF & $-0.443 * * *$ & 0.624 & $0.883^{*}$ & $2.272 * * *$ \\
\hline \multicolumn{5}{|l|}{ Interaction } \\
\hline E_ADOPT x C_LENF & -0.309 & -0.263 & -0.182 & -0.103 \\
\hline \multicolumn{5}{|l|}{ Control Variables } \\
\hline C_PS & & $-1.313 * * *$ & $-1.402 * * *$ & $-1.895 * * *$ \\
\hline C_LOD & & & -0.242 & 0.000 \\
\hline C_CORRUP & & & & $-1.222 * * *$ \\
\hline $\mathrm{C}_{-}^{-} \mathrm{LOE}$ & -0.037 & $-0.685^{* *}$ & $-0.709 * *$ & $-1.073 * * *$ \\
\hline C_FDI & 0.149 & $0.344 * * *$ & $0.394 * * *$ & $0.407 * * *$ \\
\hline Ē̄ & -0.889 & $-14.535^{* * *}$ & $-15.238 * * *$ & $-21.523^{* * *}$ \\
\hline F-value & $3.447 * * *$ & $4.174 * * *$ & $3.839 * * *$ & $4.740 * * *$ \\
\hline $\mathrm{N}$ & 87 & 87 & 87 & 87 \\
\hline $\mathrm{R}^{2}$ & 0.205 & 0.270 & 0.282 & 0.357 \\
\hline Adjusted $\mathrm{R}^{2}$ & 0.146 & 0.205 & 0.209 & 0.281 \\
\hline
\end{tabular}

AGDP3Y = Average Growth Rate of GDP per Capita Post Three Years of IFRS Adoption;

E_ADOPT $=$ IFRS Adoption (Estimate); C_LENF = Level of Enforcement

(Centered);E_ADOPT x C_LENF = Interaction between Estimated Value of Adopt and Level of Enforcement (Centered); C_PS = Political Stability (Centered); C_LOD = Level of Development $($ Centered $)$; C_Corruption $=$ Corruption $($ Centered $)$; C_LOE $=$ Level of Education $($ Centered); C_FDI = Foreign Direct Investment $($ Centered); EU = European Union; $\mathrm{p}<0.10=* ; \mathrm{p}<0.05=* * ; \mathrm{p}<0.01=* * *$

For IFRS adoption, results obtained from model 2, model 3, and model 4 of 2SLS regression (Table 4) support hypothesis 1 . However, results from model 1, model 2, and model 4 of the

\footnotetext{
${ }^{3}$ Endogeneity refers to a loop of causal relationship between the dependent and independent variable.

${ }^{4}$ Chenhall and Moers (2007) indicate that, in stage one, the independent variable, which may be endogenous, is estimated using an instrumental variable. Then, in stage two, this estimated value is used to assess the impact of the independent variable on the dependent variable. The estimated value from stage one used in the second stage controls for endogeneity.
} 
original model (Table 3) show a negative and significant relationship between IFRS adoption and the economic growth rate of a country. Endogeneity may be a reason for this negative relationship between IFRS adoption and the economic growth rate of a country. When 2SLS regression model is estimated to control endogeneity, the relationship between IFRS adoption and the economic growth rate of a country become positive and significant. Therefore, hypothesis 1 is supported. The interaction between IFRS adoption and level of enforcement is not significant in both the original model (Table 3) and the 2SLS regression model (Table 4).

Freidrich (1982), Brambor, Clark, and Golder (2005), and Green (2008) suggest that when interaction terms are involved in regression model, standard errors might become inflated. Therefore, the coefficients on the interaction term are less likely to be significant (Brambor et al., 2005). The authors recommend estimating the appropriate standard errors for interaction terms using the following formulas:

$$
\begin{aligned}
& S\left(b_{1}+b_{3} x_{2}\right)=\sqrt{\operatorname{Var}\left(b_{1}\right)+\left(x_{2}\right)^{2} \cdot \operatorname{Var}\left(b_{3}\right)+2 x_{2} \cdot \operatorname{Cov}\left(b_{1}, b_{3}\right)} \\
& S\left(b_{2}+b_{3} x_{1}\right)=\sqrt{\operatorname{Var}\left(b_{2}\right)+\left(x_{1}\right)^{2} \cdot \operatorname{Var}\left(b_{3}\right)+2 x_{1} \cdot \operatorname{Cov}\left(b_{2}, b_{3}\right)}
\end{aligned}
$$

We analyze the impact of IFRS adoption and level of enforcement at the mean values. We use estimated standard errors to show the impact of IFRS adoption (Eq. 1) and level of enforcement (Eq. 2) on the economic growth rate of a country (results not reported). Although the coefficients and the significance of the independent variables adoption and level of enforcement have changed, the change was not significant. Overall, the results do not change significantly.

\subsection{Modified Model}

The original model reported in Section 4.1 uses the average growth rate of the three years post IFRS adoption as the dependent variable. However, it is not known how long it takes for the adoption of IFRS to make an impact on the economic growth rate of adoptee countries. Therefore, we explore a different model including all independent variables proposed in the original model but a different dependent variable. In the modified model, we use growth rate of GDP per capita in 2010 (GDP2010) as the dependent variable. Using GDP2010 as the dependent variable allows measuring the impact on economic growth rate at different number of years since IFRS adoption, given that some countries adopted IFRS earlier. Possibly, more than three years are required to observe the economic benefits of IFRS adoption. In the modified model, we add number of years since adoption (NOYA) as another independent variable. NOYA indicates, for each country, the number of years from the year the country adopted IFRS to the year 2010. We also use model respecification to solve the multicollinearity problems as discussed earlier.

Similar to the variations of sample used in original model, we also use several variations of sample to test these models. These variations include: sample excluding countries with a negative growth rate (Table 5), original sample (results not reported), more conservative sample excluding countries with a negative growth rate and their matched sample (results not reported), and original sample with the log of the dependent variable (LN_GDP2010) (results not reported). Some of these variations provide consistent results with slightly different explanatory powers. 
Table 5: Ordinary Least Square Regression Analysis for Predictors of GDP2010

\begin{tabular}{|c|c|c|c|c|}
\hline Variable & Model 1 & Model 2 & Model 3 & Model 4 \\
\hline \multicolumn{5}{|l|}{ Main Effects } \\
\hline ADOPT & 0.295 & 0.240 & 0.243 & 0.286 \\
\hline C_LENF & $-0.397 * *$ & $-0.642 * * *$ & $-0.514^{*}$ & -0.192 \\
\hline NOYA & -0.349 & -0.331 & -0.340 & -0.375 \\
\hline \multicolumn{5}{|l|}{ Interaction } \\
\hline ADOPT x C_LENF & $0.410 * *$ & $0.457 * *$ & $0.469 * *$ & $0.458 * *$ \\
\hline \multicolumn{5}{|l|}{ Control Variables } \\
\hline C_PS & & 0.260 & 0.225 & 0.240 \\
\hline C_LOD & & & -0.144 & -0.021 \\
\hline C_CORRUP & & & & -0.439 \\
\hline C_LOE & 0.128 & 0.160 & 0.163 & 0.143 \\
\hline C_FDI & -0.026 & -0.026 & 0.006 & -0.031 \\
\hline $\mathrm{E} \bar{U}$ & $-0.567 * * *$ & $-0.572 * * *$ & $-0.566^{* * *}$ & $-0.562 * * *$ \\
\hline F-value & $4.655^{* * *}$ & $4.375^{* * *}$ & $3.926 * * *$ & $3.669 * * *$ \\
\hline $\mathrm{N}$ & 78 & 78 & 78 & 78 \\
\hline $\mathrm{R}^{2}$ & 0.318 & 0.337 & 0.342 & 0.354 \\
\hline Adjusted $\mathrm{R}^{2}$ & 0.249 & 0.260 & 0.255 & 0.257 \\
\hline \multicolumn{5}{|c|}{$\begin{array}{l}\text { GDP2010 = Growth Rate of GDP per Capita in 2010; ADOPT = IFRS Adoption; C_LENF = } \\
\text { Level of Enforcement; NOYA = Number of Years since Adoption; ADOPT x C_LENF = } \\
\text { Interaction between Adoption and Level of Enforcement; C_PS = Political Stability; C_LOD } \\
\text { = Level of Development; C_CORRUP = Corruption; C_LOE = Level of Education; C_FDI = } \\
\text { Foreign Direct Investment; EU = European Union; }<<0.10=* ; p<0.05=* * ; p<0.01={ }^{*} * *\end{array}$} \\
\hline
\end{tabular}

The results for the modified model, including four different variations, are displayed in Table 5. As mentioned before, two variables show multicollineartiy as indicated by VIF with values above the recommended 10 (Marquardt, 1970; Cohen et al., 1970) $($ C_LENF $=17.748$, C_CORRUP $=16.240)$. Similar to the analysis conducted in the original model, we propose four different models. We exclude political stability, level of development, and corruption from model 1 , level of development and corruption from model 2, and corruption from model 3. Model 4 consists of all variables.

The results show that the interaction between adoption and level of enforcement is positive and significant in all models. The $\mathrm{R}^{2}$ values for model 1 , model 2 , model 3 , and model 4 are $31.8 \%, 33.7 \%, 34.2 \%$, and $35.4 \%$, respectively. The $\mathrm{R}^{2}$ values for model 1 , model 2 , model 3 , and model 4 of the modified model have slightly improved compared to the $\mathrm{R}^{2}$ values for model 1 (19.7\%), model 2 (20.3\%), model 3 (22.5\%), and model 4 (25.3\%) of the original model. We find support for hypothesis 2 . 


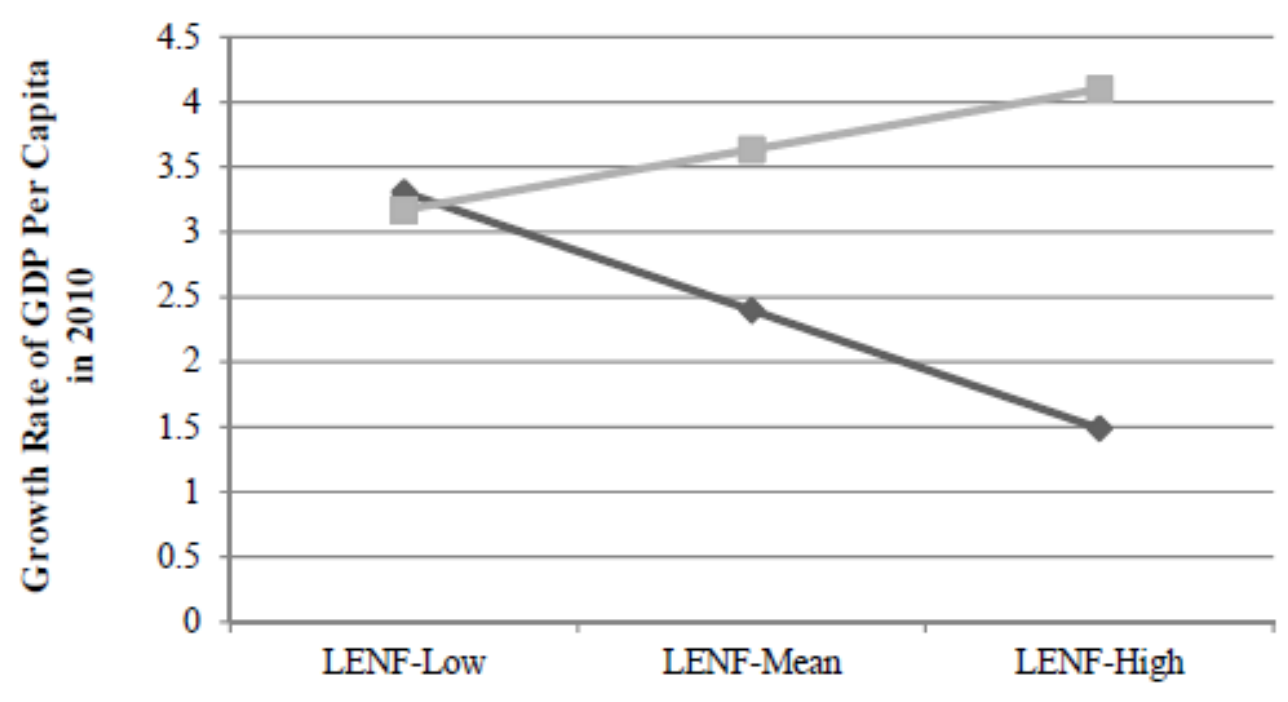

Level of Enforcement

- Non-Adoptee

Adoptee

Figure 3. Interaction Effect of IFRS Adoption and Level of Enforcement on GDP2010.

Figure 3 illustrates the interaction between IFRS adoption and the level of enforcement. The graph shows as a positive relationship with the level of enforcement and the growth rate of GDP per capita in 2010 for IFRS adoptee countries. This interaction means that as level of enforcement of IFRS adoptee countries increases, the growth rate of GDP per capita also increases. We also test for significance between the growth rate of GDP per capita in 2010 and level of enforcement. We find that at low level of enforcement (mean LENF minus 1 standard deviation), the relationship between growth rate of GDP per capita in 2010 and level of enforcement is not significant. However, at high level of enforcement (mean LENF plus 1 standard deviation), the relationship between growth rate of GDP per capita in 2010 and level of enforcement is significant.

We estimate the regression using average growth rate of GDP per capita post 5 years of IFRS adoption as a dependent variable since it is not known how long it takes for the adoption of IFRS to make an impact on the economic growth rate of adoptee countries. Using AGDP5Y as the dependent variable allows measuring the impact on economic growth rate after 5 years of IFRS adoption. We use the total percent change in the growth rate between the average growth rate of GDP per capita pre 5 and post 3 years of IFRS adoption following prevailing practice. Larson (1993) and Larson and Kenny (1995) use similar dependent variable. Again, several variations are used to estimate these dependent variables (AGDP5Y and Chg_GDP).

The results obtained from estimating regression using AGDP5Y as the dependent variable are consistent with the results obtained from estimating regression using AGDP3Y as the dependent variable with more explanatory power (results not reported). Results obtained from estimating regression using Chg_GDP do not support any hypotheses (results not reported).

\subsection{Summary of Hypotheses Testing}

Table 6 summarizes the results obtained from the original and modified models using ordinary least square and two-stage least square regression methods. 
Table 6: Summary of General Results from OLS and 2SLS Regression

\begin{tabular}{llll}
\hline Dependent Variable & Regression & Hypothesis 1 & Hypothesis 2 \\
\hline AGDP3Y & OLS & Not Supported & Not Supported \\
GDP2010 & OLS & Not Supported & Supported \\
AGDP3Y (FA) & OLS & Not Supported & Not Supported \\
AGDP5Y & OLS & Not Supported & Not Supported \\
$\Delta$ in GDP & OLS & Not Supported & Not Supported \\
AGDP3Y & 2SLS & Supported & Not Supported \\
GDP2010 & 2SLS & Supported & Not Supported \\
\hline
\end{tabular}

The first column shows the dependent variable, the second column shows the type of regression analysis used, and the third and the fourth coulmns show hypotheses. The second row shows general results obtained from the original model using average growth rate of GDP per capita post 3 years of IFRS adoption (AGDP3Y) as the dependent variable, the third row shows general results obtained from the modified model using GDP growth rate in 2010 (GDP2010) as the dependent variable, the fourth row shows general results obtained from the orignal model (AGDP3Y) as the dependent variable after creating a composite variable from some variables, the fifth row shows general results obtained from the modified model using the average growth rate of GDP per capita post 5 years of IFRS adoption (AGDP5Y) as the dependent variable, the sixth row shows general results obtained from the modified model using the total percent change in the growth rate between the average growth rate of GDP per capita pre 5 and post 3 years of IFRS adoption (Chg_GDP or $\Delta$ in GDP) as the dependent variable, and the seventh and eighth rows show general results obtained from the original model (AGDP3Y) and the modified model (GDP2010) using 2SLS to estimate the regression. Hypothsis 1 is only supported when regression is estimated using 2SLS for both original and modified model (Table 6). Hypothesis 2 is supported in the modified model (GDP2010) estimating regression using OLS (Table 6).

\section{Discussion}

We begin my research by reexamining the idea of whether the adoption of IFRS affects the economic growth rate of the adopting countries. Extant literature does not provide conclusive results of the impact of IFRS adoption on the economic growth of a country. Some studies show positive (Larson, 1993) and some negative (Larson \& Kenny, 1995), and some show no impact (Woolley, 1998) between IFRS adoption and economic growth of a country. In addition, the studies have been limited to either a particular geographic location or a group of countries selected according to their economic development. This study tries to fill the gap found in the literature by examining the impact of IFRS adoption on the economic growth of adopting countries including countries from different geographic regions and degrees of economic development. In addition, we test the influence of enforcement on the economic growth rate of the countries. The level of enforcement can leverage the gains derived from IFRS adoption. Countries may gain more benefits when they adopt IFRS and have a high level of enforcement. Therefore, we test the level of enforcement as a variable moderating the relationship between IFRS adoption and economic growth rate. The model proposed also controls for variables that influence the economic growth of a country, namely: political stability, corruption, level of education, foreign direct investment, level of development, and European Union.

In our study, we hypothesize the following effects on the economic growth rate of the IFRS adoptee countries: that the adoption of IFRS has a positive impact (Hypothesis 1) and that the level of enforcement moderates the relationship between IFRS adoption and economic 
growth (Hypothesis 2). To test these hypotheses, we estimate a regression model including all control variables.

The results from the original model including all variables indicate problems of multicollinearity. To avoid this problem, several variations of the original proposed model are tested. The original model is identified as Model 4. Contrary to expectations, there is a negative and significant relationship between IFRS adoption and economic growth rate in all variations of the original model proposed. Therefore, hypothesis 1 is not supported.

We use a second technique to avoid multicollinearity, namely creating a single composite variable that includes the variables that exhibit multicollinearity. The composite variable replaces the highly correlated variables in the regression. Combining highly correlated variables into a single measure can help solving multicollinearity problem (O'Brien, 2007). Regression results show a negative and significant relationship between IFRS adoption and economic growth rate. Therefore, hypothesis 1 is not supported. This result is similar to the general results obtained from all the variations of original model. These results suggest that adopting IFRS decreases rather than increases the growth rate of adopting countries. Tokar (2005) suggests that the initial adoption of IFRS requires a large investment for regulators and adopting countries. The benefits of IFRS adoption potentially require more than three years having a positive impact on the economic growth of a country. Larson and Kenny (1995) also find a negative relationship between IFRS adoption and the economic growth of a country. In their study, the economic growth is calculated by the total percentage change in GDP and GDP per capita from 1985 to 1989 (five years). They argue that the economic benefits from IFRS (IAS at that time) adoption may not be evident due to short time period covered in their study.

We estimate 2SLS regression to control for endogeneity. The results show the following effects on the dependent variable (average growth rate of GDP per capita post 3 years of IFRS adoption). IFRS adoption has a positive and significant impact in model 2, model 3, and model 4. The interaction between IFRS adoption and level of enforcement shows a negative relationship with the dependent variable in all models; however, the results are not statistically significant at $10 \%$ level. Results from model 2, model 3, and model 4 supports hypothesis 1 . Endogeneity may be a reason for the negative relationship found between IFRS adoption and the economic growth rate of a country in the original model (Table 3). Therefore, in the 2SLS regression model, hypothesis 1 is supported.

We include the interaction between IFRS adoption and level of enforcement to test our second hypothesis. We hypothesize that the level of enforcement positively moderates the impact of IFRS adoption on the economic growth rate of a country. We expect the coefficient of interaction term to be positive and significant. The second hypothesis is not supported in any variation of the original model. One reason for not finding support for this hypothesis could be the fact that the three-year period post IFRS adoption is not a large enough period to observe an impact on the economic growth rate of adoptee countries. It could take several years before a country can experience higher economic growth rates post IFRS adoption. This result is similar to the findings of Woolley (1998).

Therefore, we modify the original model to explore IFRS adoption over a large number of years. In this modified model, the dependent variable is growth rate of GDP per capita in 2010 (GDP2010). This modified model allows variation in the number of years since IFRS adoption; countries that adopted IFRS earlier will have a larger number of years since IFRS adoption. Possibly, more than three years are required to observe the economic benefits of IFRS adoption. In the modified model, all the independent variables of the original proposed 
model are included. We also add the number of years since adoption (NOYA) as another independent variable. NOYA indicates, for each country, the number of years from IFRS adoption to 2010. Similar to the tests on the original model, we also tests different variations of the modified model. The results indicate that the main effect of IFRS adoption is not significant. However, the interaction between adoption and level of enforcement is positive and significant. Therefore, the second hypothesis that states that the level of enforcement positively moderates the impact of IFRS adoption on the economic growth rate of a country is supported in the modified model. These results suggest that the benefits from IFRS adoption can be achieved when they are enforced. These results suggest that it may require more than 5 years for countries to observe the benefits from IFRS adoption. The results also suggest that benefits depend on the level of enforcement.

Findings obtained from this study can help regulators from the countries that have not adopted IFRS yet in making adopting decisions. This research provides evidence of the benefits of IFRS adoption. These benefits, however, are contingent on the level of enforcement. Countries adopting IFRS should plan in advance on the mechanisms to enforce the standards. Also, international organizations could develop guidelines to promote IFRS enforcement.

To Analysts, the results suggest the need to consider IFRS and enforcement jointly; expected benefits of IFRS cannot be achieved without enforcement mechanisms. Analysts should consider that the reports from firms from countries where IFRS have been adopted, might not necessarily comply with IFRS, as compliance depends on the level of enforcement.

\section{Limitations and Future Research.}

The results from this study should be interpreted considering the following limitations. One limitation is the operationalization of the level of enforcement of IFRS. We are using the level of enforcement, which is a general indicator of a country and does not refer to financial reporting specifically. At this point, country level IFRS compliance indices are not available. Future research can be conducted to test the economic consequences of IFRS adoption using level of IFRS compliance as a moderator variable when they are available.

Also, other factors that might play a crucial role in the economic growth of a country are not included in the present research. For example, productivity, population growth, healthier workforce and ease of doing business can have a significant impact on the economic growth of a country (Sekirin, 2010). However, due to the limited sample size, we can include only a small number of control variables in my model. Therefore, we do not include these factors in our model.

Another limitation is that it is a correlational study. Correlational studies are not a test of causality. Although these studies can suggest that there is a relationship between two or more variables, they cannot imply causation. Since this is a correlational study, we cannot prove if a particular variable is causing a change in the other variable. In addition, there might be a problem of endogeneity. We try to mitigate this problem by estimating the models using 2SLS regression. However, there might be other independent variables that are endogenous to the dependent variable.

Another limitation of this study is the availability of the data. Our sample is limited to the available data; therefore, the reduced sample size may be a problem. A larger sample may provide more robust results by strengthening the sample. 


\section{Acknowledgement}

Thank you for Dr. Gary Braun, Dr. Rick Francis, and Dr. Nathan Ashby of the University of Texas at El Paso for their valuable comments.

\section{References}

Armstrong, C. S., Barth, M. E., Jagolinzer, A. D., \& Riedl, E. J. (2008). Market Reation to the Adoption of IFRS in Europe. Working Paper, University of Pennsylvania.

Arnold, P. J. (2005). Disciplining Domestic Regulation: the World Trade Organization and the Market for Professional Services. Accounting, Organziations and Society, 30, 299-330.

Ashraf, J., \& Ghani, W. I. (2005). Accounting development in Pakistan. The International Journal of Accounting , 40, 175-201.

Ball, R. (2006). International Financial Reporting Standards (IFRS): Pros and Cons for Investors. Accounting and Business Research , 36, 5-27.

Bardhan, P. (1997). Corruption and Development: A Review of Issues. Journal of Economic Literature, 35(3), 1320-1346.

Barth, M. E., Landsman, W. R., \& Lang, M. H. (2008). International Accounting Standards and Accounting Quality. Journal of Accounting Research , 46 (3), 467-498.

Benston, G. J., Bromwich, M., Litan, R. E., \& Wagenhofer, A. (2006). Worldwide Financial Reporting: The Development and Future of Accounting Standards. New York: Oxford University Press.

Brambor, T., Clark, W. R., \& Golder, M. (2005). Understanding Interactions Models: Improving Empirical Analyses. Political Analysis, 13, 1-20.

Chenhall, R. H., \& Moers, F. (2007). The Issue of Endogeneity within Theory-Based, Quantitative Management Accounting Research. European Accounting Review, 16, 173-195.

Coffee, J. C. (2002). Racing towards the Top?: The Impact of Cross-Listings and Stock Market Competition on International Corporate Governance. Columbia Law Review, 102(7), 1757-1831.

Cohen, J., Cohen, P., West, S. G., \& Aiken, L. S. (2003). Applied Multiple Regression/Correlation Analysis for the Behavioral Sciences (3rd ed.). Mahwah, New Jersey: Lawrence Erlbaum Associates, Inc.

Collins, S. H. (1989). The Move to Globalization: Is a Common International Accounting Language Feasible? Journal of Accountancy, 167, 82-85.

Daske, H., Hail, L., Leuz, C., \& Verdi, R. (2008). Mandatory IFRS Reporting Around the World: Early Evidence on the Economic Consequences. Journal of Accounting Research , 46, $1085-1142$. 
De Mello, L. R. (1999). Foreign Direct Investment-Led Growth: Evidence from Time Series and Panel Data. Oxford Economic Papers, 51, 133-151.

Deloitte. (2010). IFRSs in your Pocket 2010. Retrieved June 14, 2011, from Deloitte: http://www.deloitte.com/assets/Dcom-Turkey/Local\%20Assets/Documents/turkey-en_audit_I FRS2010_250510.pdf

Drabek, Z., \& Payne, W. (2002). The Impact of Tranparency on Foreign Direct Investment. Journal of Economic Integration, 17(4), 777-810.

Gornik-Tomaszewski, S., \& McCarthy, I. N. (2003). Review of Business. Cooperation between FASB and IASB to Achieve Convergence of Accounting Standards, 24(2), 52-59.

Hicks, B. (2010, July). IFRS: Room for Improvement? Retrieved June 13, 2011, from Hong Kong Institute of Certified Public Accountants, By All Accounts: http://www.hkicpa.org.hk/file/media/section2_become_a_hk_cpa/recog-oversea-bodies/usefu 1-article/name-change.pdf

Hope, O.-K., Jin, J., \& Kang, T. (2006). Empirical Evidence on Jurisdictions that Adopt IFRS. Journal of International Accounting Research, 5(2), 1-20.

Jermakowicz, E. K. (2004). Effects of Adoption of International Financial Reporting Standards in Belgium: The Evidence from BEL-20 Companies. Accounting in Europe , 1, 51-70.

Jermakowicz, E. K., \& Gornik-Tomaszewski, S. (2006). Implementing IFRS from the Perspective of EU Publicly Traded Companies. Journal of International Accounting, Auditing and Taxation , 15, 170-196.

Kaufmann, D., Kraay, A., \& Mastruzzi, M. (2008). Governance Matters VII: Aggregate and Individual Governance Indicators 1996-2007. Policy Research Working Paper 4654.

Kaufmann, D., Kraay, A., \& Mastruzzi, M. (2009). Governance Matters VIII: Aggregate and Individual Governance Indicators 1996-2008. Policy Research Working Paper 4978.

Kwok, W. C., \& Sharp, D. (2005). Power and International Accounting Standard Setting: Evidence from Segment Reporting and Intangible Assets Project. Accounting, Auditing \& Accoutability Journal, 18(1), 74-99.

La Porta, R., Lopez-de-Silanes, F., Shleifer, A., \& Vishny, R. W. (1998). Law and Finance. Journal of Political Economy, 106 (6), 1113-1155.

Lambert, R., Leuz, C., \& Verrecchia, R. E. (2007). Accounting Information Disclosure, and the Cost of Capital. Journal of Accounting Research , 45, 385-420.

Lang, M. H., Lins, K. V., \& Miller, D. P. (2003). ADRs, Analysts, and Accuracy: Does Cross Listing in the United States Improve a Firm's Information Environment and Increase Market 
Value? Journal of Accounting Research, 41(2), 317-345.

Larson, R. K. (1993). International Accounting Standards and Economic Growth: An Empirical Investigation of their relationship in Africa. Research in Third World Accounting , 2, 27-43.

Larson, R. K., \& Kenny, S. Y. (1995). An Empirical Analysis of International Accounting Standards, Equity Markets, and Economic Growth in Developing Countries. Journal of International Financial Management and Accounting , 6 (2), 130-157.

Larson, R. K., \& Kenny, S. Y. (1996). Accounting Standard-Setting Strategies and Theories of Economic Development: Implications for the Adoption of International Accounting Standards. Advances in International Accounting , 9, 1-20.

Lee, C.-W. J. (1987). Accounting Infrastructure and Economic Development. Journal of Accounting and Public Policy, 6, 75-85.

Leuz, C., \& Verrecchia, R. E. (2000). The Economic Consequences of Increased Disclosure. Journal of Accounting Research , 38, 91-124.

Marquardt, D. W. (1970). Generalized Inverses, Ridge Regression, Biased Linear Estimation, and Nonlinear Estimation. Technometrics, 12, 591-612.

Mir, M. Z., \& Rahaman, A. S. (2005). The Adoption of International Accounting Standards in Bangladesh. Accounting, Auditing \& Accountability Journal , 18, 816-841.

O'Brien, R. M. (2007). A Caution Regarding Rules of Thumb for Variance Inflation Factors. Quality \& Quantity, 41, 673-690.

Radebaugh, L. H., \& Gray, S. J. (2002). International Accounting and Multinational Enterprises (5th ed.). New York: John Wiley \& Sons, Inc.

Radebaugh, L. H., Gray, S. J., \& Black, E. L. (2006). International Accounting and Multinational Enterprises. New York: John Wiley \& Sons, Inc.

Rao, M. J. (1998). Development in the Time of Globalization. Working Paper Series \# 1, University of Massachusetts Amherst, 1-74.

Roussey, R. S. (1992). Developing International Accounting and Auditing Standards for World Markets. Journal of International Accounting, Auditing and Taxation , 1 (1), 1-11.

Samuels, J. M., \& Piper, A. G. (1985). International Accounting: A Survey. New York: St. Martin's Press.

Sekirin, E. (2010, July 07). Major Factors Influencing Economic Growth. Retrieved June 13, 2011, from www.ehow.com: http://www.ehow.com/list_6706424_major-factors-influencing-economic-growth.html 


\section{Macrothink}

International Journal of Accounting and Financial Reporting

ISSN 2162-3082

Soderstrom, N. S., \& Sun, K. J. (2007). IFRS Adoption and Accounting Quality: A Review. European Accounting Review , 16, 675-702.

Street, D. L., \& Gray, S.J. (1999) How Wide is the Gap between IASC and U.S. GAAP? Impact of the IASC Comparability Project and Recent International Developments. International Accounting, Auditing, \& Taxation, 8(1), 133-164.

Tokar, M. (2005). Convergence and the Implementation of a Single Set of Global Standards: The Real-life Challenge. Accounting in Europe, 2(1), 47-68.

Woolley, R. (1998). International Accounting Standards and Economic Growth, an Empirical Investigation of their Relationship in Asia. Working paper series. Australia: School of Accounting and Law, RMIT.

Wyatt, A. R., \& Yospe, J. F. (1993, July). Wake-up Call to American Business: International Accounting Standards are on the Way. Journal of Accountancy, 80-85.

Zeghal, D., \& Mhedhbi, K. (2006). An Analysis of the Factors Affecting the Adoption of International Accounting Standards by Developing Countries. The International Journal of Accounting , 41, 373-386. 
Appendix

Appendix 1. Matched Sample

\begin{tabular}{|c|c|c|c|}
\hline Adoptee & Non-Adoptee & Adoptee & Non-Adoptee \\
\hline Jordan & Israel & Norway & Egypt, Arab Republic \\
\hline Guyana & Sri Lanka & Poland & Montenegro \\
\hline Malawi & Bolivia & Portugal & Switzerland \\
\hline Guatemala & Macedonia & Romania & Vietnam \\
\hline Jamaica & Thailand & Slovak Republic & Singapore \\
\hline Ukraine & Maldives & Slovenia & Tunisia \\
\hline United Arab Emirates & Cote d'Ivoire & South Africa & Burkina Faso \\
\hline Iraq & Zimbabwe & Spain & Australia \\
\hline Serbia & Chile & Sweden & Uganda \\
\hline Tanzania & Kyrgyz Republic & United Kingdom & New Zealand \\
\hline Austria & Mexico & Mauritius & Belize \\
\hline Belgium & United States & Botswana & Nigeria \\
\hline Bulgaria & Georgia & Croatia & Cape Verde \\
\hline Cyprus & Columbia & Fiji & Canada \\
\hline Czech Republic & Malaysia & Ghana & Philippines \\
\hline Denmark & Costa Rica & Panama & Bangladesh \\
\hline Estonia & China & Tajikistan & Cambodia \\
\hline Finland & Swaziland & & \\
\hline France & Dominican Republic & & \\
\hline Germany & Syrian Arab Republic & & \\
\hline Greece & Lao PDR & & \\
\hline Hungary & Bhutan & & \\
\hline Iceland & Mali & & \\
\hline Ireland & Mozambique & & \\
\hline Italy & Benin & & \\
\hline Kazakhstan & Azerbaijan & & \\
\hline Latvia & Trinidad and Tobago & & \\
\hline Liechtenstein & Niger & & \\
\hline Lithuania & Belarus & & \\
\hline Luxembourg & Turkey & & \\
\hline Malta & St. Kitts and Nevis & & \\
\hline Namibia & Indonesia & & \\
\hline Netherlands & Libya & & \\
\hline Nicaragua & Cameron & & \\
\hline
\end{tabular}

\section{Copyright Disclaimer}

Copyright reserved by the author(s).

This article is an open-access article distributed under the terms and conditions of the Creative Commons Attribution license (http://creativecommons.org/licenses/by/3.0/). 